Pacific Journal of Mathematic 


\title{
GROUPS OF SQUARE-FREE ORDER ARE SCARCE
}

\author{
Michael E. Mays
}

\begin{abstract}
We devise an upper bound for $B(n)$, the number of nonisomorphic groups whose orders are square-free and no larger than $n$, and a lower bound for $T(n)$, the number of nonisomorphic groups whose orders are no larger than $n$. It is then noted that $B(n)=o(T(n))$.
\end{abstract}

An open problem is to find a formula for $N(n)$, the number of nonisomorphic groups of order $n$. Balash [1] discovered such a formula in the special case where $n$ is square-free, and Higman [4] and Sims [6] developed an asymptotic formula for the number of groups of order a power of a prime. In this paper we use Balash's result to determine an upper bound for $B(n)$, where

$$
B(n)=\sum_{\substack{k \leq n \\ k \text { square-free }}} N(k),
$$

and the work of Higman and Sims to bound $T(n)$, given by

$$
T(n)=\sum_{k \leqq n} N(k),
$$

from below.

Higman's result, as refined by Sims, is

Lemma 1. Let $A=A(n, p)$ be defined by $\log _{p}\left(N\left(p^{n}\right)\right)=A n^{3}$. Then $A=2 / 27+O\left(n^{-1 / 3}\right)$.

Higman originally offered $2 / 27$ as the function in the lower bound for $A$ with error term $O\left(n^{-1}\right)$ and 2/15 in the upper bound. Sims reduced the upper bound to $2 / 27+O\left(n^{-1 / 3}\right)$. The lower bound is all we need, and the constant is not important as long as it is positive.

THEOREM 1. There exists a positive constant $c$ such that

$$
T(n) \gg n^{c \log ^{2} n} \text {. }
$$

Proof. Let $2^{m}<n \leqq 2^{m+1}$. Then for $n>1$,

$$
T(n) \geqq T\left(2^{m}\right) \gg 2^{k m^{3}} \geqq n^{c \log ^{2} n} .
$$

Murty and Murty [5] show that $T(n) \gg n \log \log \log n$, which is enough to conclude, with a result of Erdös and Szekeres [2], that abelian groups are scarce. They then ask about nilpotent groups. Their lower bound grows more slowly than $n^{2}$, whereas the bound 
in Theorem 1 grows faster than any polynomial in $n$.

An upper bound for $T(n)$ of

$$
n^{a n^{2 / 3} \log n},
$$

with $a$ explicitly given, was provided by Gallagher [3]. Every group counted in the proof of Theorem 1 is a p-group and hence nilpotent. For $\mathscr{N}(n)$ the number of nonisomorphic nilpotent groups of order no greater than $n$, then,

$$
n^{c \log ^{2} n} \ll \mathscr{N}(n) \leqq n^{a n^{2 / 3} \log n},
$$

and if the lower bound were the correct order of magnitude of $\mathscr{N}(n)$ then we could say that almost all groups are nilpotent.

If $n$ is square-free, the number of groups of order $n$ is determined by the unitary congruences among the prime divisors of $n$. Such a congruence exists if, for $p$ and $q$ prime factors of $n, p \equiv 1(\bmod q)$. If none exist, then $(n, \phi(n))=1$, where $\phi(n)$ is the totient function of Euler, and in that case it was shown by Szele [7] that there is exactly one group of order $n$. Roughly, the more congruences there are the more nonisomorphic groups of order $n$ there can be. Balash's formula below gives the number of groups of a square-free order $n$ in terms of the unitary congruences among $n$ 's prime factors.

LEMMA 2. For $k$ square-free and $m \mid k$, let $\mathfrak{r}(k / m, p)$ be the number of prime divisors $q$ of $k / m$ for which $q \equiv 1(\bmod p)$. Then

$$
N(k)=\sum_{m|k| k} \prod_{p \nmid m} \frac{p^{1(k / m, p)}-1}{p-1} .
$$

Thus, for instance, $N(6)=($ summand for 1$)+($ summand for 2$)+$ (summand for 3$)+($ summand for 6$)=1+1+0+0=2$.

This is used in

TheOREM 2. $B(n) \ll n^{2} \log \log n$.

Proof. For $k$ square-free, Lemma 2 gives

$$
N(k) \leqq \sum_{m \mid k} \prod_{p \nmid m} p^{\mathfrak{\imath}(k / m, p)}
$$

But

$$
\begin{aligned}
\prod_{p \mid m} p^{\imath(k / m, p)} & =\prod_{q \mid k / m} \prod_{p \mid(q-1, m)} p \\
& =\prod_{q|k| m}(q-1, m) \leqq \prod_{q|k| m} q=k / m .
\end{aligned}
$$




$$
N(k) \leqq \sum_{m ! k} k / m=\sigma(k) \ll k \log \log k
$$

and

$$
B(n)=\sum_{\substack{k \leq n \\ k \text { square-free }}} N(k) \ll n^{2} \log \log n .
$$

Now we have

THEOREM 3. $B(n)=o(T(n))$.

The author would like to thank the referee for several helpful suggestions. Some of these results appeared in the author's $\mathrm{Ph}$. D. thesis, written under the guidance of Professor Raymond Ayoub at the Pennsylvania State University.

\section{REFERENCES}

1. E. E. Balash, On the number of nonisomorphic groups whose order is not divisible by the square of a prime, Izv. Vyss. Uchebn. Zav. Math., 53 (1966), 1-8.

2. P. Erdös and G. Szekeres, Über die Anzahl der Abelschen Gruppen gegebener Ordnung und über ein verwendtes zahlentheoretisches Problem, Acta Scient. Math., 7 (1934-35), 95-102.

3. P. X. Gallagher, Counting finite groups of given order, Math. Zeitschrift, 102 (1967), 236-237.

4. G. Higman, Enumerating p-groups. I: Inequalities, Proc. London Math. Soc., 10 (1960), 24-30.

5. M. Ram Murty and V. Kumar Murty, The number of groups of a given order, (preprint).

6. C. Sims, Enumerating p-groups, Proc. London Math. Soc., 15 (1965), 151-166.

7. T. Szele, Über die endlichen ordnungszahlen zu denen nur eine Gruppe gehirt, Commenj. Math. Helv., 20 (1947), 265-67.

Received February 27, 1978 and in revised form August 27, 1979.

West Virginia University

Morgantown, WV 26506 



\section{PACIFIC JOURNAL OF MATHEMATICS}

\section{EDITORS}

DONALD BABBITT (Managing Editor)

University of California

Los Angeles, CA 90024

Hugo RossI

University of Utah

Salt Lake City, UT 84112

C. C. MOORE and ANDREW OGG

University of California

Berkeley, CA 94720

\section{J. DugundjI}

Department of Mathematics

University of Southern California

Los Angeles, CA 90007

R. FinN and J. Milgram

Stanford University

Stanford, CA 94305

\section{ASSOCIATE EDITORS}
E. F. BeCKENBACH
B. H. Neumann
F. WoLF
K. YoSHIDA

\section{SUPPORTING INSTITUTIONS}

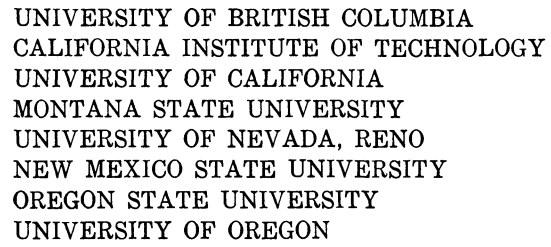

UNIVERSITY OF BRITISH COLUMBIA CALIFORNIA INSTITUTE OF TECHNOLOGY UNIVERSITY OF CALIFORNIA MONTANA STATE UNIVERSITY UNIVERSITY OF NEVADA, RENO NEW MEXICO STATE UNIVERSITY OREGON STATE UNIVERSITY UNIVERSITY OF OREGON

\author{
UNIVERSITY OF SOUTHERN CALIFORNIA \\ STANFORD UNIVERSITY \\ UNIVERSITY OF HAWAII \\ UNIVERSITY OF TOKYO \\ UNIVERSITY OF UTAH \\ WASHINGTON STATE UNIVERSITY \\ UNIVERSITY OF WASHINGTON
}

The Supporting Institutions listed above contribute to the cost of publication of this Journal, but they are not owners or publishers and have no responsibility for its content or policies.

Mathematical papers intended for publication in the Pacific Journal of Mathematics should be in typed form or offset-reproduced, (not dittoed), double spaced with large margins. Please do not use built up fractions in the text of the manuscript. However, you may use them in the displayed equations. Underline Greek letters in red, German in green, and script in blue. The first paragraph or two must be capable of being used separately as a synopsis of the entire paper. Please propose a heading for the odd numbered pages of less than 35 characters. Manuscripts, in triplicate, may be sent to any one of the editors. Please classify according to the scheme of Math. Reviews, Index to Vol. 39. Supply name and address of author to whom proofs should be sent. All other communications should be addressed to the managing editor, or Elaine Barth, University of California, Los Angeles, California, 90024.

50 reprints to each author are provided free for each article, only if page charges have been substantially paid. Additional copies may be obtained at cost in multiples of 50 .

The Pacific Journal of Mathematics is issued monthly as of January 1966. Regular subscription rate: $\$ 84.00$ a year (6 Vols., 12 issues). Special rate: $\$ 42.00$ a year to individual members of supporting institutions.

Subscriptions, orders for numbers issued in the last three calendar years, and changes of address shoud be sent to Pacific Journal of Mathematics, P.O. Box 969, Carmel Valley, CA 93924, U.S.A Old back numbers obtainable from Kraus Periodicals Co., Route 100, Millwood, NY 10546.

PUBLISHED BY PACIFIC JOURNAL OF MATHEMATICS, A NON-PROFIT CORPORATION

Printed at Kokusai Bunken Insatsusha (International Academic Printing Co., Ltd.). 8-8, 3-chome, Takadanobaba, Shinjuku-ku, Tokyo 160, Japan. 


\section{Pacific Journal of Mathematics}

\section{Vol. 91, No. 2 December, 1980}

Victor P. Camillo and Julius Martin Zelmanowitz, Dimension modules ... . . 249

Yonina S. Cooper, Stable sequences in pre-abelian categories ........... 263

Chandrakant Mahadeorao Deo and H. Ship-Fah Wong, On Berry-Esseen approximation and a functional LIL for a class of dependent random fields.........................................

H. P. Dikshit and S. N. Dubey, $|C, 1|$ summability of series associated with

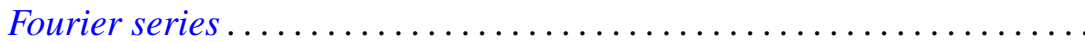

M. Edelstein, On the homomorphic and isomorphic embeddings of a semiflow into a radial flow.

Gilles Godefroy, Compacts de Rosenthal ..................... 293

James Guyker, Commuting hyponormal operators ................ 307

Thomas Eric Hall and Peter R. Jones, On the lattice of varieties of bands of

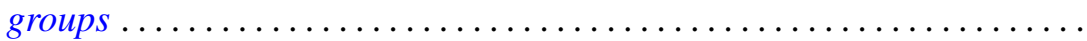

Taqdir Husain and Saleem H. Watson, Topological algebras with orthogonal Schauder bases ....................................

V. K. Jain, Some expansions involving basic hypergeometric functions of two variables. . .

Joe W. Jenkins, On group actions with nonzero fixed points ........... 363

Michael Ellsworth Mays, Groups of square-free order are scarce ........ 373

Michael John McAsey, Canonical models for invariant subspaces... 377

Peter A. McCoy, Singularities of solutions to linear second order elliptic partial differential equations with analytic coefficients by approximation methods...

Terrence Millar, Homogeneous models and decidability.

Stephen Carl Milne, A multiple series transformation of the very well poised

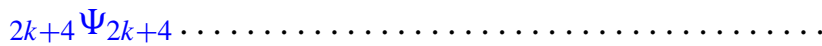

Robert Olin and James E. Thomson, Irreducible operators whose spectra are spectral sets...

Robert John Piacenza, Cohomology of diagrams and equivariant singular

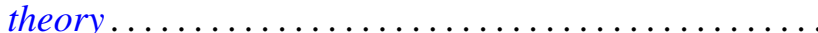

Louis Jackson Ratliff, Jr., Integrally closed ideals and asymptotic prime divisors

Robert Breckenridge Warfield, Jr., Cancellation of modules and groups and stable range of endomorphism rings.................

B. J. Day, Correction to: "Locale geometry" ...............

Stanley Stephen Page, Correction to: "Regular FPF rings" ... 